\title{
Changes in Caribbean coral disease prevalence after the 2005 bleaching event
}

\author{
Aldo Cróquer*, Ernesto Weil \\ Department of Marine Sciences, University of Puerto Rico, PO Box 908, Lajas 00667, Puerto Rico
}

\begin{abstract}
Bleaching events and disease epizootics have increased during the past decades, suggesting a positive link between these 2 causes in producing coral mortality. However, studies to test this hypothesis, integrating a broad range of hierarchical spatial scales from habitats to distant localities, have not been conducted in the Caribbean. In this study, we examined links between bleaching intensity and disease prevalence collected from 6 countries, 2 reef sites for each country, and 3 habitats within each reef site $(\mathrm{N}=6 \times 2 \times 3=36$ site-habitat combinations) during the peak of bleaching in 2005 and a year after, in 2006. Patterns of disease prevalence and bleaching were significantly correlated $($ Rho $=0.58, \mathrm{p}=0.04)$. Higher variability in disease prevalence after bleaching occurred among habitats at each particular reef site, with a significant increase in prevalence recorded in 4 of the 10 site-habitats where bleaching was intense and a non-significant increase in disease prevalence in 18 out of the 26 site-habitats where bleaching was low to moderate. A significant linear correlation was found $(\mathrm{r}=0.89, \mathrm{p}=0.008)$ between bleaching and the prevalence of 2 virulent diseases (yellow band disease and white plague) affecting the Montastraea species complex. Results of this study suggest that if bleaching events become more intense and frequent, disease-related mortality of Caribbean coral reef builders could increase, with uncertain effects on coral reef resilience.
\end{abstract}

KEY WORDS: Coral bleaching $\cdot$ Coral diseases $\cdot$ Caribbean corals $\cdot$ Thermal anomalies

\section{INTRODUCTION}

Coral diseases and bleaching are thought to be primary causes of recent coral reef deterioration (Hoegh-Guldberg 1999, Hughes et al. 2003, Aronson et al. 2005). Coral diseases can reduce fecundity of coral hosts (Petes et al. 2003, Weil et al. 2009, this Special), produce local and regional population decline (Gladfelter 1982, Jolles et al. 2002, Kim et al. 2004, Richardson \& Voss 2005), and trigger important shifts in coral communities (Aronson \& Precht 2001, Nugues 2002, Borger \& Steiner 2005). However, studies to elucidate why and to predict when epizootic events will occur are not yet available (Harvell et al. 2007), partly because coral disease dynamics remain poorly understood. Understanding coral disease dynamics and population responses at different spatial and temporal scales is an important step necessary to control, or at least to mitigate, the impact of diseases on coral reefs. For instance, detecting environmental drivers of disease and characterizing stressing factors that make the hosts more susceptible might help in developing management strategies aimed at ameliorating the occurrence of epizootics. Pursuing this goal, however, requires improving our knowledge on coral-pathogen interactions and how these interactions vary in the context of environmental change at different spatial scales (Harvell et al. 2004).

The disease triangle model (Stevens 1960) is frequently used to describe how changes in the environment affect host-pathogen interactions. According to this model, pathology occurs depending on the balance among 3 forces: (1) virulence, i.e. diseaseinduced mortality rate (Altizer et al. 2001) and/or the ability of a pathogen to infect and spread within a host (Ward et al. 2007), (2) host resistance, i.e. the ability of an organism to maintain its immunity or to counteract 
a disease agent (Stedman 2000), and (3) an environment favorable for disease development. The abiotic environment can affect either the host or the pathogen, shifting the interaction in favor of one or the other (Blanford et al. 2003, Thomas \& Blanford 2003, Ward et al. 2007). Among many environmental parameters, temperature has been shown to affect host-pathogen interactions in invertebrates (Blanford et al. 2003). For corals, temperature is particularly relevant because it affects their physiology (reviewed by Brown 1997). For instance, temperature stress is known to disrupt animal-zooxanthellae stability (Glynn \& D'Croz 1990, Lesser 2004), which leads to coral bleaching (i.e. the expulsion of zooxanthellae and/or loss of their function). This stress condition produces metabolic and physiological disorders in the coral host (Brown 1997). Furthermore, recent molecular evidence demonstrates that significant shifts from diverse bacterial communities present in healthy corals to Vibrio-dominated assemblages occur prior and during bleaching (Bourne et al. 2008). Bleached corals therefore might become metabolically compromised and more susceptible to pathogen infections.

Natural seasonality of water temperature is linked with the dynamics of diseases in coral reef ecosystems (Bruckner \& Bruckner 1997, Harvell et al. 2002, 2009, Kuta \& Richardson 2002, Richardson \& Kuta 2003, Altizer et al. 2006, Rodriguez \& Cróquer 2008). For corals, thermal anomalies have been proposed to facilitate the emergence of diseases and/or to increase the frequency and intensity of epizootic events (Harvell et al. 2002). This idea is supported by various experimental and correlative studies conducted with Gorgonia ventalina-Aspergillus sydowii and Oculina patagonica-Vibrio shiloi model systems in which the pathogen grows in detriment to the host (Israely et al. 2001, Banin et al. 2003, Ben-Haim et al. 2003, Ward et al. 2007). The evidence showing a direct and positive correlation between coral bleaching and coral disease epizootics (i.e. coral-disease-bleaching hypothesis) is scarce, but is increasing (Brandt \& McManus 2009). In the Caribbean, for example, local observations seem to correlate bleaching with coral epizootic events (e.g. Harvell et al. 2001, Miller et al. 2006, 2009, Muller et al. 2008), but studies considering a broad range of hierarchical spatial scales including different habitats within reef sites and countries across the Caribbean region have not been conducted. Likewise, in the Pacific Ocean, only 1 study found a correlation between coral disease epizootics and coral bleaching events on the inshore Great Barrier Reef (Jones et al. 2004). Bruno et al. (2007) showed a correlation between sea surface temperature anomalies combined with coral cover and the increase in the prevalence of white syndromes in the Great Barrier Reef.
Since coral bleaching events are expected to increase in the near future (Hoegh-Guldberg 1999, Hoegh-Guldberg et al. 2007), understanding the role of bleaching as a potential driver of coral diseases must be a research priority. It is important to investigate whether disease epizootics are correlated with episodes of coral bleaching and to examine the generality of this correlation in the field at different spatial scales. The summer of 2005 was the warmest of the last 2 decades, which resulted in prolonged and intense thermal stress across the Caribbean region (Fig. 1). Because thermal anomalies were differently distributed across the Caribbean, bleaching intensity (i.e. the percent of bleached corals) also varied, resulting in a geographical gradient of bleaching. This large-scale bleaching event presented a unique opportunity to test whether (1) coral disease epizootics and coral bleaching are correlated, (2) species affected by bleaching were more susceptible to infections, and (3) disease prevalence increased across a wide range of spatial scales (i.e. countries, reef sites, and habitats).

\section{MATERIALS AND METHODS}

Sampling design. For the purposes of this study, bleaching was classified as intense (30 to $60 \%$ of bleached corals), moderate (10 to $29 \%$ ), or low $(<10 \%)$. If bleaching and disease prevalence were positively linked, we expected a significant increase in disease prevalence in sites where bleaching was intense and no significant increase where bleaching was moderate to low. Surveys to examine correlations between bleaching and disease were performed in Grenada, Curaçao, Panamá, Puerto Rico, Cayman Islands, and Bermuda, the northern-most coral reef distribution in the Caribbean-Atlantic (Fig. 2). In each country, 2 reefs at least $5 \mathrm{~km}$ apart were surveyed using 5 permanent belt transects $\left(10 \times 2 \mathrm{~m}=20 \mathrm{~m}^{2}\right)$ each at 3 different depth intervals (shallow: $<4 \mathrm{~m}_{\text {; }}$ intermediate: 5-12 $\mathrm{m}_{i}$ and deep: $>15 \mathrm{~m}$ ). All colonies within a transect were counted and checked for signs of disease and bleaching. The average prevalence of each disease affecting the major corals was estimated as the number of diseased colonies over the total number of colonies in each species/genus. Surveys were conducted during the peak of bleaching (August-September to early December 2005) and repeated at the same localities during the same months in 2006. Because of the wide geographical scope of this study, it was impossible to repeat the sampling at each site during different months, and therefore our design cannot detect the natural within-seasonal temporal variability (i.e. spatial and temporal patterns are confounded for the sampling period). Despite this limitation, temperature 

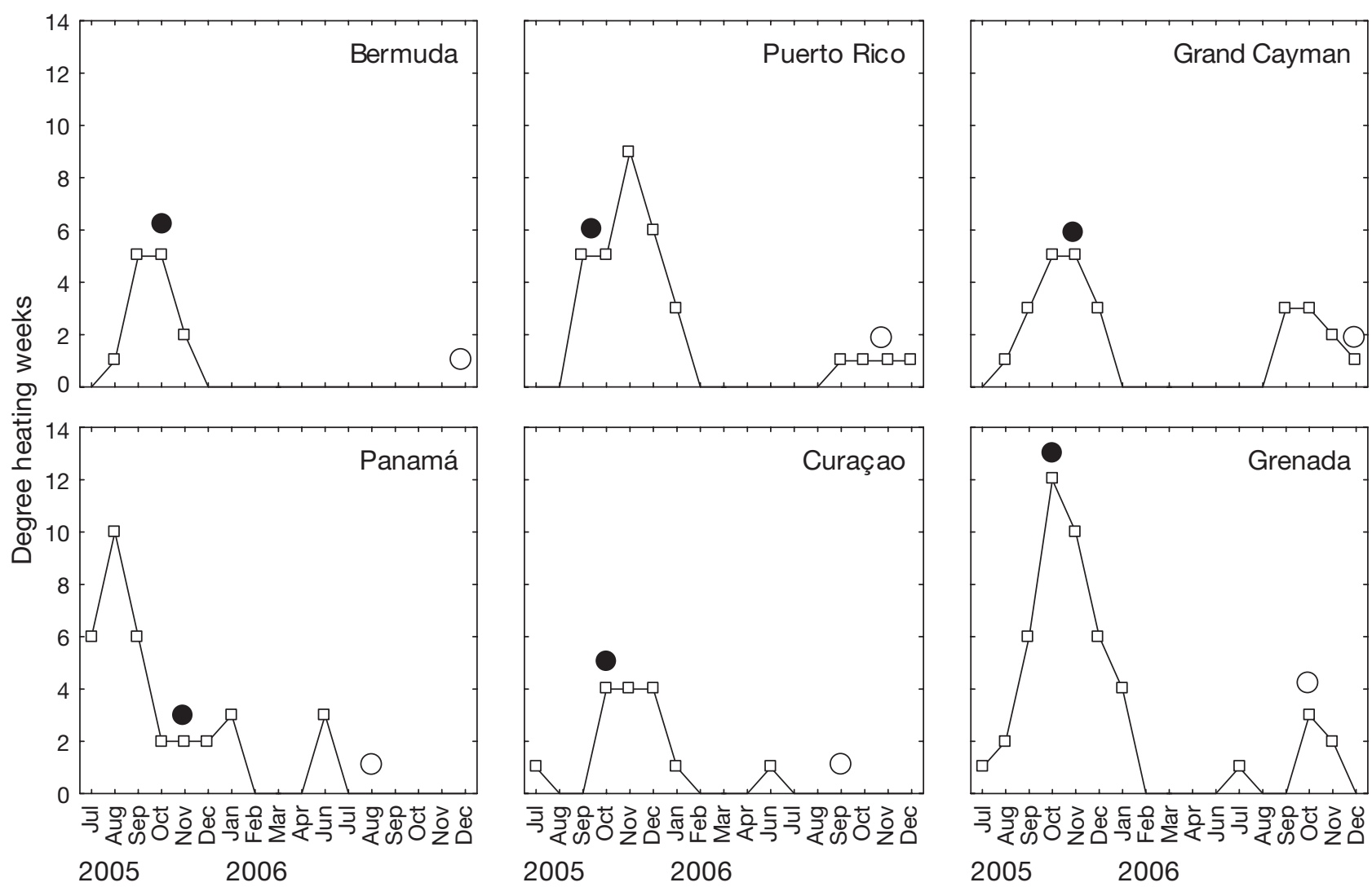
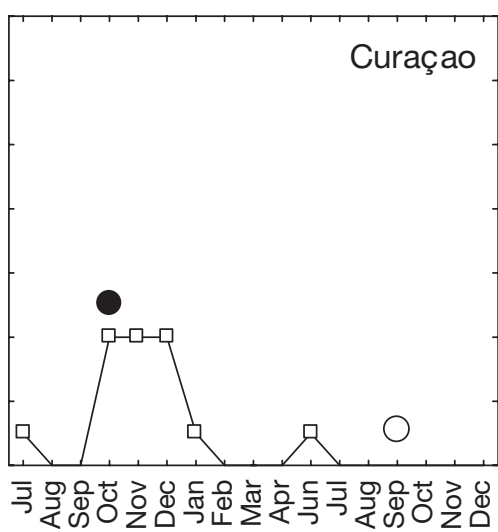
2005 2006

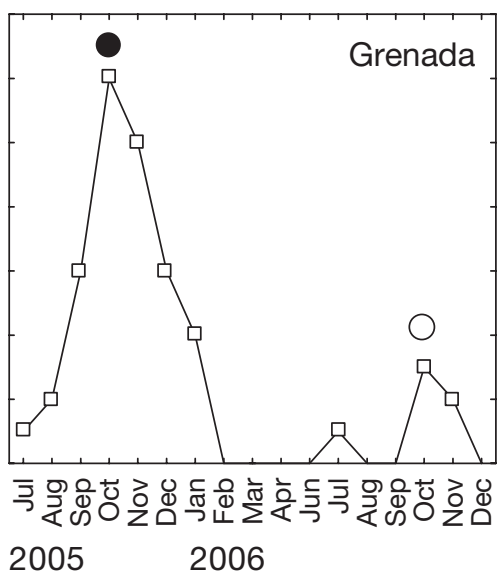

Fig. 1. Cumulative degree heating weeks (i.e. number of weeks with temperatures $1{ }^{\circ} \mathrm{C}$ above the expected values for a particular month) across sites for the study period. Black and white circles represent the dates of surveys in 2005 and 2006 , respectively

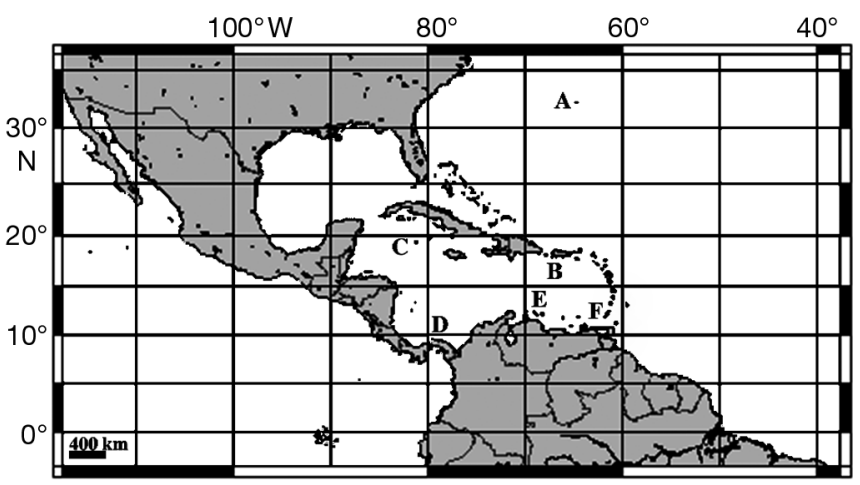

Fig. 2. Location of 6 Caribbean countries surveyed during 2005 and 2006. (A) Bermuda, (B) Puerto Rico, (C) Grand Cayman, (D) Panamá, (E) Curaçao and (F) Grenada. Map created at www.aquarius.geomar.de/

anomalies were present at all sites during the first surveys of 2005, and these temperature anomalies had disappeared and/or decreased by the time surveys were repeated in 2006 (Fig. 1).

Six major reef-building and disease-susceptible scleractinian genera that are abundant and geographically widely distributed were selected for this study (Montastraea, Diploria, Agaricia, Siderastrea, Stephanocoenia, and Porites). For most genera, colonies of all spe- cies in the same genus were pooled to avoid the inclusion of rare species present at fewer sites and to exclude from the analysis species that were rarely affected by disease but were frequently affected by bleaching. The genus Montastraea only included $M$. faveolata, $M$. annularis, and $M$. franksi because $M$. cavernosa is seldom affected by diseases or bleaching. The genus Porites included P. astreoides, P. porites, and $P$. furcata, the most common species at our survey sites, whereas Agaricia was represented by all species we surveyed in this genus. For the purposes of this study, only colonies that were severely bleached ( $>50 \%$ of their surface area) were included to reduce the possibility of masking a potential correlation between disease prevalence and bleaching with colonies that might not have been compromised physiologically.

Data analysis. An unbalanced design comprising 4 factors was used for hypothesis testing: depth (fixed and crossed), site (random and nested within country), country (fixed and crossed), and time (fixed and crossed). Five $20 \mathrm{~m}^{2}$ belt transects (replicates) were surveyed in each of the 3 depth intervals at every site, with the exception of Culebrita, where only 4 transects were surveyed at each depth interval because of the 
length of the reef. Total bleaching and disease prevalence were analyzed separately using a univariate permutation analysis of variance (PERMANOVA) based on Euclidean distance (Anderson 2001). The same approach was used for the multivariate matrices of bleaching and disease but using the Bray-Curtis index as similarity measurement (Anderson 2001). Pairwise post hoc comparisons based on permutations were performed among statistically significant fixed factors. This approach was used because data were not normal and variances were relatively similar (Underwood 1999). A multivariate correlation (RELATE) between the bleaching and disease matrices was performed using PRIMER to link multispecies patterns of bleaching and diseases (Clarke \& Warwick 2001). A Spearman correlation analysis was then performed only for those sites, habitats, diseases, and species where bleaching and diseases were linked. This analysis was performed to avoid masking a potential positive correlation between bleaching and disease because each site could have different species composition with different susceptibilities to bleaching and/or diseases.

\section{RESULTS}

Spatial patterns of bleaching in 2005 and coral diseases in 2006 were significantly correlated (RELATE, Rho $=0.58$, $\mathrm{p}=0.04$ ) and a significant and positive linear relationship between the percent of bleached corals in 2005 and coral disease prevalence in 2006 was also found ( $r=0.89, p=0.008$, Fig. 3 ). Some of the most common species in the genera Montastraea, Diploria, Agaricia, Siderastrea, Stephanocoenia, and Porites that were severely affected by bleaching in 2005 showed signs of disease in 2006. The Montastraea species complex, Diploria spp., and Agaricia spp. were mostly affected by yellow band disease (YBD), white plague disease (WPD), Caribbean ciliate infections
Table 1. Classification of sites and depth habitats (shallow: $<4 \mathrm{~m}_{\text {; }}$ intermediate: 5-12 $\mathrm{m}$; deep: $>15 \mathrm{~m}$ ) according to bleaching intensity in 2005 and disease prevalence in 2006. NI: no increase; IN: statistically significant increase; MI: moderate (non-significant) increase; DE: significant decrease; WPD: white plague disease; CCI: Caribbean ciliate infections; Multi: multiple diseases; YBD: yellow band disease

\begin{tabular}{|c|c|c|c|c|}
\hline $\begin{array}{l}\text { Site } \\
\text { Habitat }\end{array}$ & $\begin{array}{c}\text { Bleaching } \\
\text { intensity }(\%)\end{array}$ & $\begin{array}{c}\text { Prevalence } \\
\text { (2006) }\end{array}$ & Disease & $\begin{array}{l}\text { Confirms } \\
\text { prediction }\end{array}$ \\
\hline \multicolumn{5}{|l|}{ Bermuda } \\
\hline \multicolumn{5}{|l|}{ Chub Cut } \\
\hline Shallow & $<10$ & NI & & Yes \\
\hline Intermediate & $<10$ & NI & & Yes \\
\hline Deep & $<10$ & NI & & Yes \\
\hline \multicolumn{5}{|l|}{ Rita's } \\
\hline Shallow & $<10$ & NI & & Yes \\
\hline Intermediate & $<10$ & NI & & Yes \\
\hline Deep & $<10$ & NI & & Yes \\
\hline \multicolumn{5}{|l|}{ Curaçao } \\
\hline \multicolumn{5}{|l|}{ Sea Aqua } \\
\hline Shallow & $<10$ & NI & & Yes \\
\hline Intermediate & $<10$ & NI & & Yes \\
\hline Deep & $<10$ & NI & & Yes \\
\hline \multicolumn{5}{|l|}{ Habitat } \\
\hline Shallow & $<10$ & IN & WPD, CCI, Multi & No \\
\hline Intermediate & $<10$ & IN & WPD, CCI, Multi & No \\
\hline Deep & $<10$ & NI & & Yes \\
\hline \multicolumn{5}{|l|}{ Cayman } \\
\hline \multicolumn{5}{|l|}{ South Point } \\
\hline Shallow & $10-30$ & MI & YBD & Yes \\
\hline Intermediate & $<10$ & NI & & Yes \\
\hline Deep & $<10$ & NI & & Yes \\
\hline \multicolumn{5}{|l|}{ Andes } \\
\hline Shallow & $<10$ & NI & & Yes \\
\hline Intermediate & $10-30$ & MI & YBD & Yes \\
\hline Deep & $10-30$ & MI & YBD & Yes \\
\hline \multicolumn{5}{|l|}{ Panamá } \\
\hline \multicolumn{5}{|l|}{ STRI } \\
\hline Shallow & $<10$ & IN & WPD, CCI, Multi & No \\
\hline Intermediate & $10-30$ & MI & WPD, CCI, Multi & Yes \\
\hline Deep & $30-60$ & NI & & No \\
\hline \multicolumn{5}{|l|}{ Roldan } \\
\hline Shallow & $10-30$ & MI & WPD, CCI & Yes \\
\hline Intermediate & $10-30$ & NI & & No \\
\hline Deep & $10-30$ & NI & & No \\
\hline \multicolumn{5}{|l|}{ Puerto Rico } \\
\hline \multicolumn{5}{|l|}{ Guanica } \\
\hline Shallow & $10-30$ & $\mathrm{DE}$ & & No \\
\hline Intermediate & $10-30$ & $\mathrm{DE}$ & & No \\
\hline Deep & $10-30$ & NI & & No \\
\hline \multicolumn{5}{|l|}{ Culebrita } \\
\hline Shallow & $30-60$ & IN & WPD & Yes \\
\hline Intermediate & $30-60$ & NI & & No \\
\hline Deep & $30-60$ & $\mathrm{DE}$ & & No \\
\hline \multicolumn{5}{|l|}{ Grenada } \\
\hline \multicolumn{5}{|l|}{ Flamingo } \\
\hline Shallow & $30-60$ & NI & & No \\
\hline Intermediate & $30-60$ & NI & & No \\
\hline Deep & $30-60$ & NI & & No \\
\hline \multicolumn{5}{|l|}{ Valleys } \\
\hline Shallow & $30-60$ & IN & YBD & Yes \\
\hline Intermediate & $30-60$ & IN & YBD & Yes \\
\hline Deep & $30-60$ & IN & YBD & Yes \\
\hline
\end{tabular}




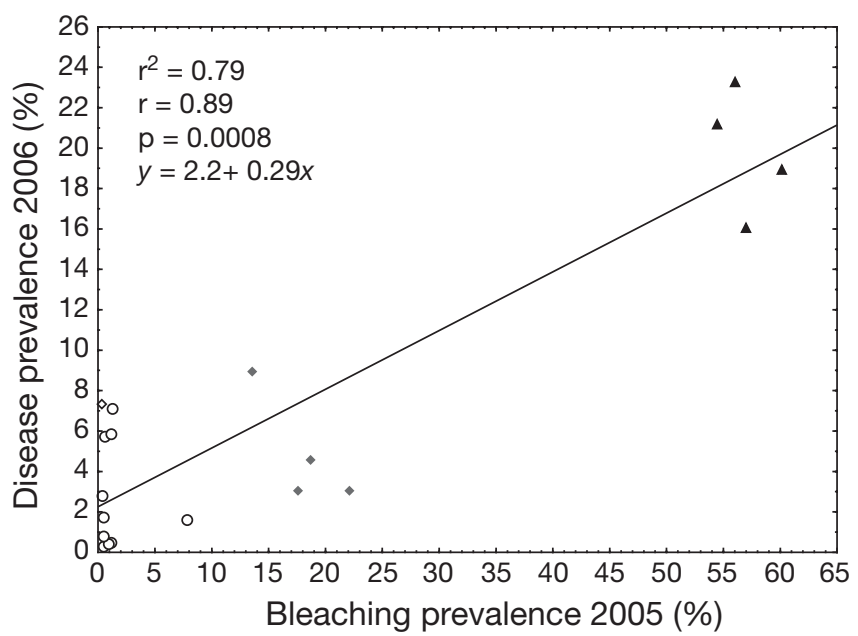

Fig. 3. Correlation between the mean percentage of bleached corals in 2005 and the mean prevalence of yellow band disease (Montastraea spp.), white plague disease (Montastraea spp., Diploria spp., Agaricia spp.), Caribbean ciliate infections (Diploria spp.), and multiple diseases (Montastraea spp. and Diploria spp.) in 2006. «: significant increase in disease prevalence, : slight but not significant increase, o: no increase in disease prevalence

(CCI), and multiple diseases (i.e. diseases such as WPD, YBD, black band disease, and CCI occurring in the same colony). Combined, these diseases were mostly responsible for both expected and unexpected increases in disease prevalence in 2006 (Table 1). For instance, in the shallow depth interval of Habitat (Curaçao), significant increases in the prevalence of WPD, CCI, and multiple diseases were recorded despite the low bleaching intensity at this site. In Valleys, where bleaching was intense, prevalence of YBD also increased significantly (Table 1).

Bleaching intensity varied significantly between habitats at each reef site and across localities (Table 2). Severe bleaching was recorded along the 3 depths in Grenada (range: 45-60\%), the intermediate habitats in the 2 reef sites of Puerto Rico $(40 \pm 1.7 \% \mathrm{SE})$, and deep habitats $(>15 \mathrm{~m})$ in reefs of Panamá $(40 \pm$

Table 2. Three-factorial multivariate permutational analysis of variance based on Euclidean distance for the percent of bleached corals ( $\mathrm{N}=144$ belt transects). Factors: country (Co, crossed and fixed), depth habitat (Ha, crossed and fixed), reef site (Re, nested within country and random)

\begin{tabular}{|lrrrrc|}
\hline Source & df & SS & MS & Pseudo-F & p \\
\hline Co & 5 & 28703.00 & 5740.70 & 4.34 & 0.062 \\
Ha & 2 & 1839.30 & 919.66 & 1.36 & 0.307 \\
Re $($ Co $)$ & 6 & 7933.30 & 1322.20 & 5.23 & 0.001 \\
Co $\times$ Ha & 10 & 5944.50 & 594.45 & 0.88 & 0.59 \\
Re $($ Co $) \times$ Ha & 12 & 8131.10 & 677.60 & 2.68 & 0.004 \\
Residual & 318 & 80396.00 & 252.82 & & \\
\hline
\end{tabular}

$3.2 \% \mathrm{SE}$ ). Bleaching was low in Curaçao and Bermuda and showed moderate levels at all the other reef sites and depths (Fig. 4). In each country, coral genera affected by bleaching also differed across depth intervals (Table 3). The Montastraea species complex was severely bleached at all depths surveyed in Grenada (23.2-51.8\%) and Cayman Island (16-44\%). In the 2 reefs surveyed in Puerto Rico, most bleached corals were in the genus Agaricia (46.7-59.6\%, Table 3). Other reefs in Puerto Rico, however, showed up to $90 \%$ of the Montastraea species complex completely bleached (E. Weil \& A. Cróquer unpubl. data). In Panamá, Stephanocoenia intersepta displayed severe bleaching in deeper and intermediate habitats (77.4$66.8 \%$ ), while in shallow habitats, Agaricia spp. and $S$. intersepta were equally affected but at a low level of severity $(10 \%$, Table 3$)$. By 2006, the percent of bleached corals had significantly decreased in all countries (Table 4), with Curaçao and Bermuda showing no changes in bleaching prevalence between years (Fig. 5A).

Disease prevalence also varied significantly between depth intervals within reefs and among reef sites (Table 5), with a 4-fold increase in the deep habitat of Valleys (Grenada) and a 2-fold increase in the shallow habitat of Culebrita (Puerto Rico) in 2006 (Fig. 5B). Spatial patterns of bleaching in 2005 and disease in 2006 were linked as $60 \%$ (22) of the 36 possible cases (i.e. 6 countries $\times 2$ sites $\times 3$ depth habitats $=36$ ) confirmed our predictions: (1) disease prevalence in corals increased significantly in 4 of 10 reefs that experienced intense bleaching, (2) a slight but not significant increase in coral diseases was recorded in 5 of 10 sitehabitats where bleaching intensity was moderate, and (3) no increase in disease prevalence was recorded in 13 of 16 cases where bleaching was low (Fig. 5B, Table 1).

\section{DISCUSSION}

This study shows that overall, disease prevalence in 2006 was significantly correlated with bleaching intensity in 2005 at many reef sites. The bleaching event affected a wide range of coral species, whereas diseases only affected few species. Furthermore, not all diseases increased in prevalence after the 2005 bleaching event; however, reef-building corals were particularly susceptible to disease after bleaching stress. Thus, even though bleaching and disease were linked, other factors (not considered here) seem to affect disease dynamics.

Caribbean YBD (affecting Montastraea faveolata), WPD, and multiple diseases (affecting Montastraea, Diploria, and Agaricia species complexes) were the 

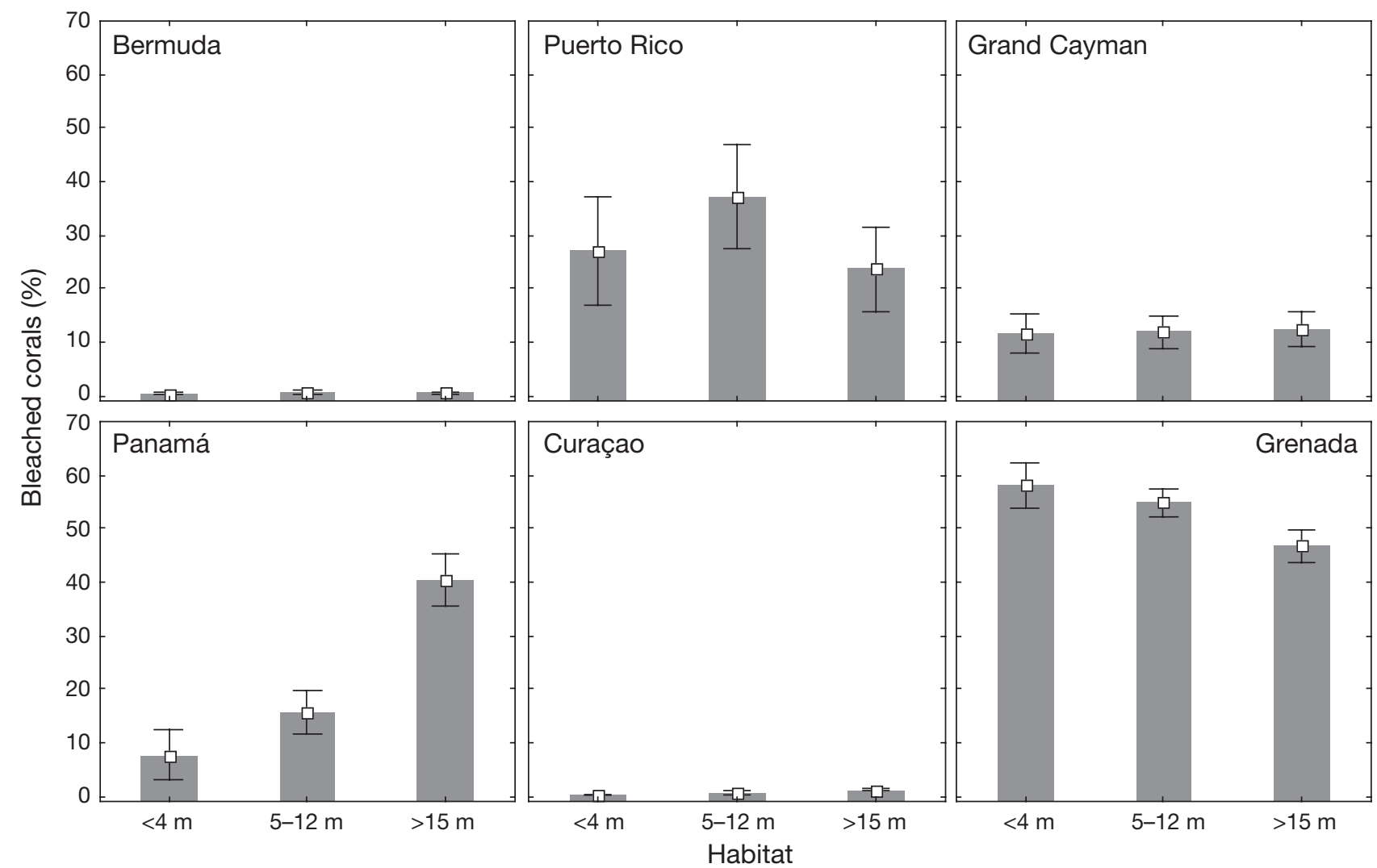

Fig. 4. Mean \pm SE of bleached corals (\%) for 6 Caribbean countries and 3 depth habitats during the summer of 2005

Table 3. Total percent of bleached corals in 2005 in 6 major reef building genera across countries and 3 depth habitats (shallow: $<4 \mathrm{~m}_{\text {; }}$ intermediate: 5-12 $\mathrm{m}_{\text {; }}$ deep $>15 \mathrm{~m}$ )

\begin{tabular}{|c|c|c|c|c|c|c|}
\hline $\begin{array}{l}\text { Country } \\
\text { Habitat }\end{array}$ & Agaricia & Diploria & Montastraea & Porites & Siderastrea & $\begin{array}{c}\text { Stephanocoenia } \\
\text { intersepta }\end{array}$ \\
\hline \multicolumn{7}{|l|}{ Bermuda } \\
\hline \multicolumn{7}{|l|}{ Shallow } \\
\hline \multirow{2}{*}{\multicolumn{7}{|c|}{$\begin{array}{l}\text { Intermediate } \\
\text { Deep }\end{array}$}} \\
\hline & & & & & & \\
\hline \multicolumn{7}{|l|}{ Puerto Rico } \\
\hline Shallow & 59.6 & 9.3 & 21.4 & 17.7 & & 10.6 \\
\hline Intermediate & 54.8 & 15.3 & 39.7 & 24.2 & 13.9 & 22.2 \\
\hline Deep & 46.7 & 34.6 & 32.3 & 15 & 27.2 & \\
\hline \multicolumn{7}{|l|}{ Grand Cayman } \\
\hline Shallow & 12.7 & & 16 & & & \\
\hline Intermediate & 7 & & 27.5 & & & \\
\hline Deep & 10.6 & 6 & 44 & & & 5.9 \\
\hline \multicolumn{7}{|l|}{ Panamá } \\
\hline Shallow & 10 & & 10.7 & & & 10 \\
\hline Intermediate & 16.3 & & 14.7 & & 8 & 66.8 \\
\hline Deep & 34.9 & & & & 16.8 & 77.4 \\
\hline \multicolumn{7}{|l|}{ Curaçao } \\
\hline \multicolumn{7}{|l|}{ Shallow } \\
\hline \multicolumn{7}{|l|}{ Intermediate } \\
\hline Deep & & & & 30 & & \\
\hline \multicolumn{7}{|l|}{ Grenada } \\
\hline Shallow & 89.7 & 38.9 & 56.7 & 23.2 & 36.1 & 20 \\
\hline Intermediate & 89.6 & 36.2 & 82.3 & 34 & 47.1 & 28.3 \\
\hline Deep & 58.4 & 22.9 & 62.8 & 51.8 & 57.7 & 45.9 \\
\hline
\end{tabular}


Table 4. Four-factorial multivariate permutational analysis of variance based on Euclidean distance for the percent of bleached corals ( $\mathrm{N}=177$ belt transects). Factors as in Table 2, with the addition of year ( $\mathrm{Yr}$, crossed and fixed)

\begin{tabular}{|lrrrrc|}
\hline Source & df & \multicolumn{1}{c}{ SS } & \multicolumn{1}{c}{ MS } & Pseudo- $F$ & $\mathrm{p}$ \\
\hline $\mathrm{Co}$ & 5 & 35237.00 & 7047.50 & 5.71 & 0.039 \\
$\mathrm{Ha}$ & 2 & 924.91 & 462.45 & 2.07 & 0.184 \\
$\mathrm{Ye}$ & 1 & 21351.00 & 21351.00 & 607.41 & 0.001 \\
$\mathrm{Re}(\mathrm{Co})$ & 6 & 7403.20 & 1233.90 & 10.47 & 0.001 \\
$\mathrm{Co} \times \mathrm{Ha}$ & 10 & 6397.10 & 639.71 & 2.86 & 0.031 \\
$\mathrm{Co} \times \mathrm{Yr}$ & 5 & 1404.80 & 117.07 & 0.99 & 0.454 \\
$\mathrm{Ha} \times \mathrm{Yr}$ & 2 & 60.78 & 30.39 & 0.26 & 0.794 \\
$\operatorname{Re}(\mathrm{Co}) \times \mathrm{Ha}$ & 12 & 2682.60 & 223.55 & 1.90 & 0.033 \\
$\operatorname{Re}(\mathrm{Co}) \times \mathrm{Yr}$ & 6 & 209.95 & 34.99 & 0.30 & 0.934 \\
$\mathrm{Co} \times \mathrm{Ha} \times \mathrm{Yr}$ & 10 & 1826.60 & 182.66 & 1.56 & 0.233 \\
$\operatorname{Re}(\mathrm{Co}) \times \mathrm{Ha} \times \mathrm{Yr}$ & 12 & 27984.00 & 5596.80 & 159.81 & 0.001 \\
$\mathrm{Re}(2 i d u a l$ & 282 & 33223.00 & 117.81 & & \\
\hline
\end{tabular}

Table 5. Four-factorial multivariate permutational analysis of variance based on Euclidean distance for the prevalence of coral diseases at $\mathrm{N}=77$ belt transects. Factors as in Table 2, with the addition of year ( $\mathrm{Yr}$, crossed and fixed)

\begin{tabular}{|lccccc|}
\hline Source & df & SS & MS & Pseudo- $F$ & $p$ \\
\hline Ye & 1 & 281.26 & 281.26 & 4.6494 & 0.072 \\
Co & 5 & 1420.2 & 284.04 & 1.0558 & 0.408 \\
$\mathrm{Ha}$ & 2 & 74.77 & 37.385 & 0.72026 & 0.505 \\
$\operatorname{Re}(\mathrm{Co})$ & 6 & 1614.6 & 269.11 & 11.7 & 0.001 \\
$\mathrm{Yr} \times \mathrm{Co}$ & 5 & 410.96 & 82.193 & 1.3574 & 0.359 \\
$\mathrm{Yr} \times \mathrm{Ha}$ & 2 & 39.793 & 19.896 & 0.43324 & 0.629 \\
$\mathrm{Co} \times \mathrm{Ha}$ & 10 & 779.98 & 77.998 & 1.5014 & 0.246 \\
$\mathrm{Yr} \times \operatorname{Re}(\mathrm{Co})$ & 6 & 363.4 & 60.566 & 2.6332 & 0.015 \\
$\operatorname{Re}(\mathrm{Co}) \times \mathrm{Ha}$ & 12 & 623.53 & 51.96 & 2.2591 & 0.011 \\
$\mathrm{Yr} \times \mathrm{Co} \times \mathrm{Ha}$ & 10 & 374.7 & 37.47 & 0.81525 & 0.626 \\
$\operatorname{Re}(\mathrm{Co}) \times \mathrm{Ha} \times \mathrm{Yr}$ & 12 & 551.63 & 45.969 & 1.9986 & 0.027 \\
$\operatorname{Re}(\mathrm{Hidual}$ & 282 & 6486.2 & 23.001 & & \\
\hline
\end{tabular}

only conditions that increased in prevalence in 2006. For instance, the prevalence of YBD increased from 5 to $20 \%$ in deeper habitats where it was at low prevalence in 2005 , and from 5 to $12 \%$ at intermediate depth habitats at Valleys reef in Grenada where M. franksi and $M$. faveolata dominate reef communities. The high levels of disease prevalence in Grenada in 2006 coincided with reports of WPD and YBD epizootics following bleaching events in other localities (Jones et al. 2004, Miller et al. 2006). In another study, Muller et al. (2008) documented an increase of disease prevalence in colonies of Acropora palmata monitored after the 2005 bleaching event in Hawksnest Bay, St. John, US Virgin Islands (USVI). During the same period, recurrent epizootic events of WPD also reduced coral cover by about $51 \%$ for the $M$. annularis species complex and 78 to $85 \%$ for other important reef builders in St. John and St. Croix, USVI (Miller et al. 2009).

Despite the positive and strong correlation between bleaching intensity and coral disease prevalence, 5 of the 10 sites where bleaching was intense did not show increases in disease prevalence. In the deepest habitat of Culebrita, Puerto Rico, disease prevalence significantly decreased, probably due to the extensive coral mortality before the 2006 surveys. In shallow and intermediate depths at Habitat in Curaçao and in shallow habitats in Panamá, a significant increase in the prevalence of WPD, CCI, and multiple diseases was recorded, despite the low bleaching intensity in 2005. Therefore, bleaching might promote an increase in coral diseases as shown in this and other studies (Muller et al. 2008, Brandt \& McManus 2009), but this might not be always the case.

Other local environmental/biological factors operating at smaller spatial and/or different temporal scales could also play an important role as drivers of coral disease. For instance, the history of host populations (Harvell 1990) at each site (i.e. whether and how often a particular site had been affected by diseases or bleaching), differences in susceptibility among and within coral populations, composition and structure of coral communities, and environmental seasonality of each site could determine alone and/or combined the levels of disease prevalence following a bleaching event.

The level of exposure to parasites in wildlife populations is known to affect host resistance (Ebert et al. 1998). It is expected that host species exposed to a diverse array of parasites should harbor a variety of resistant alleles or a repertoire of inducible defenses (Altizer et al. 2003). Conversely, parasites are more likely to colonize host populations with only few genotypes (i.e. low genetic diversity, Poulin et al. 2000). If this is the case, coral disease prevalence might not increase after a bleaching event on reef sites where coral populations are more resistant (or genetically diverse) and/or with corals having differential susceptibility. For example, Dube et al. (2002) found evidence of directional selection for Gorgonia ventalina, with Aspergillus sidowii being capable of eliminating susceptible individuals from sites with high disease pressure. Vollmer \& Kline (2008) demonstrated the existence of genotypes of Acropora cervicornis with different susceptibility to white band disease. Colonies of $G$. ventalina exposed to $A$. sidowii have various defense mechanisms to infection (Harvell \& Fenical 1989, Dube et al. 2002, Ward et al. 2007, Mydlarz et al. 2008), and these 


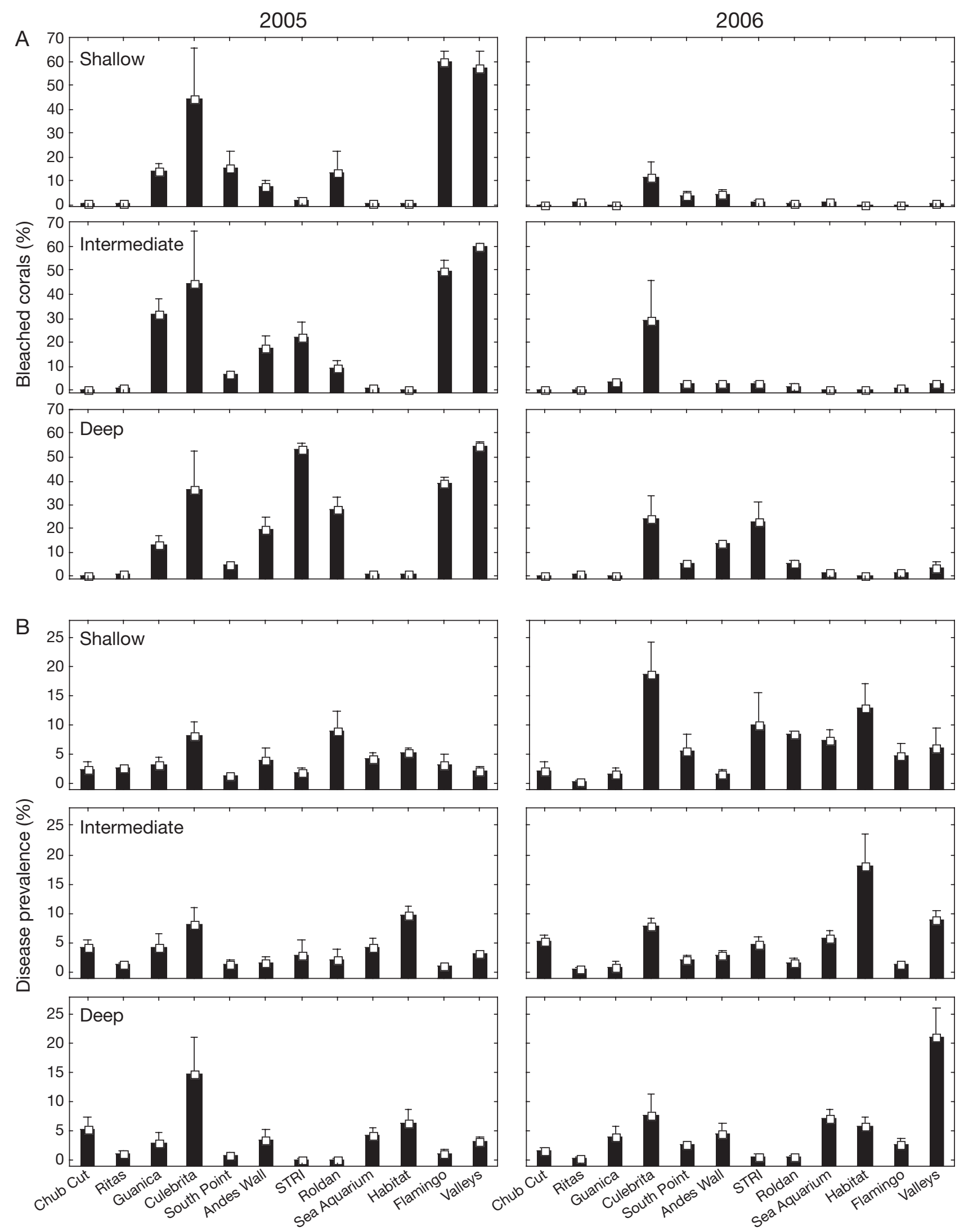

Fig. 5. Temporal changes in the mean \pm SE (A) percent of bleached corals and (B) disease prevalence across 6 Caribbean countries, 2 sites per country, and 3 depth habitats (shallow: $<4 \mathrm{~m}_{\text {i }}$ intermediate: $5-12 \mathrm{~m}$; deep: $>15 \mathrm{~m}$ ) per site 
mechanisms vary among populations and within individuals of the same species (Ward 2007). The level of exposure to thermal stress also affects coral resistance to bleaching. For instance, Thompson \& van Woesik (2009) found that corals frequently exposed to thermal stress showed reduced bleaching during the 2005 and 2006 in sites severely affected by thermal stress in 1998.

Coral community composition is another factor that could drive a positive correlation between bleaching severity and increase of disease prevalence. While the majority of Caribbean coral species are susceptible to bleaching, fewer are affected by coral diseases. In this study, only species susceptible to both bleaching and the most virulent and common diseases were selected to avoid masking the link between bleaching and disease prevalence. The inclusion of species highly susceptible to bleaching but seldom affected by diseases would decrease the relationship between bleaching intensity and disease prevalence. For instance, in sites dominated by Porites spp., Madracis spp., and any other species highly resistant to disease but susceptible to bleaching, no relationship between these variables will be noticed.

Coral cover and density are also important factors explaining the link between bleaching and diseases. In the Caribbean, several studies have reported extensive epizootic events in oceanic islands where coral cover is high (e.g. Cróquer et al. 2005, Bruckner \& Bruckner 2006). Similar results have been found in the Great Barrier Reef, where sites with high coral cover and frequent thermal anomalies experienced an increase in the prevalence of white syndromes (Bruno et al. 2007). Thus, sites with high coral cover and/or density of colonies (e.g. Valleys and Sea Aquarium; E. Weil \& A. Cróquer unpubl. data) could facilitate disease transmission (i.e. density-dependent rate of transmission) as happens for many terrestrial diseases (Dobson \& Hudson 1998). In plant systems, species diversity has been shown to affect disease transmission (i.e. disease-diversity hypothesis, Mitchell et al. 2002). Low plant diversity normally leads to higher abundance of dominant species, which increases disease transmission rates (Mitchell et al. 2002). Species diversity is also relevant for disease dynamics depending on the nature of the pathogen (e.g. host-specific or host-generalist). For instance, Gilbert \& Sousa (2002) found that hostspecialized pathogens dominate low-richness forests where host density is relatively high for dominant species, whereas high-richness forests favor hostgeneralist pathogens. However, these predictions do not necessarily apply to corals, as shown by the low correlation between disease prevalence and diversity found by Ward et al. (2006).
Seasonality of coral diseases should be considered as a factor influencing the correlation between bleaching and coral diseases. The epizootiology of several coral diseases displayed a strong seasonal pattern with peaks of prevalence during warmer months (e.g. Bruckner \& Bruckner 1997, Kuta \& Richardson 2002, Richardson \& Kuta 2003, Rodriguez \& Cróquer 2008). The effect of bleaching as a trigger for epizootics could be enhanced if bleaching (or high water temperature) events coincide with or anticipate seasons when disease prevalence naturally increases. Due to the large geographical scope of this study, it was impossible to repeat all the surveys during the same month; however, field campaigns were conducted during the warmer months to increase as much as possible the probability of sampling during the peaks of coral disease prevalence.

In conclusion, this study shows that coral bleaching and disease prevalence are positively correlated. Higher variability in the response of disease to bleaching was recorded at small rather than large spatial scales, i.e. depths within reef sites. Of the 8 diseases recorded in our surveys, prevalence increased only for YBD, WPD, CCI, and multiple diseases among Montastraea faveolata, M. franksi, Diploria labyrinthiformis, and D. strigosa. Results from this and other studies suggest that if bleaching events continue to increase in frequency and intensity, more epizootics of highly virulent coral diseases such as WPD and YBD could potentially occur in the near future. These diseases produce high tissue/colony mortality and reduce the reproductive output (fitness) of the major reefbuilding species in the Caribbean (Bruckner \& Bruckner 2006, Miller et al. 2006, Weil et al. 2009), which hamper potential recovery of local populations and could have extensive negative consequences for the future of Caribbean coral reefs.

Acknowledgements. Funding for this study was provided by the Global Environment Facility (GEF) and World Bank Coral Reef Targeted Research and Capacity Building program through the Coral Disease Working Group. Partial funding for work in Puerto Rico was provided by the NOAA-CRES project (\#NA170P2919) and logistical support by the Department of Marine Sciences, University of Puerto Rico. We thank S. Piontek and the Curaçao Sea Aquarium in Curaçao; The Habitat dive shop, C. Morrall (Department of Biology, University of Grenada), and Devotion 2 Ocean dive shop in Grenada; H. Guzmán, C. Guevara, and the Smithsonian Tropical Research Institute in Panamá; J. Ward, K. Coates, S. Manuel, and Captain A. Nash of the Department of Conservation Services in Bermuda; and G. Fairbanks, C. McCoy, and the Department of the Environment in Grand Cayman for their kind welcome and logistical support. K. Flynn and E. Irizarry helped with surveys in Puerto Rico and commented on earlier versions of this manuscript. K. Kim and 3 anonymous reviewers provided critical comments to improve this manuscript. 


\section{LITERATURE CITED}

Altizer AP, Smith GW, Kim K (2001) Characterization of Aspergillus sidowii (Thom et Church), a fungal pathogen of Caribbean sea fans. Hydrobiologia 460:105-111

Altizer AP, Harvell DC, Friedle E (2003) Rapid evolutionary dynamics and disease threats to biodiversity. Trends Ecol Evol 18:589-596

Altizer S, Dobson A, Hosseini P, Hudson P, Pascual M, Rohani $P$ (2006) Seasonality and the dynamics of coral disease. Ecol Lett 9:467-484

Anderson MJ (2001) A new method for non-parametric multivariate analysis of variance. Austral Ecol 26:32-46

> Aronson RB, Precht WF (2001) White-band diseases and the changing face of Caribbean coral reefs. Hydrobiologia 460:25-38

Aronson RB, Macintyre IG, Lewis SA, Hilbun NL (2005) Emergent zonation and geographic convergence of coral reefs. Ecology 86:2586-2600

Banin E, Vassilakos D, Orr E, Martinez RJ, Rosenberg E (2003) Superoxide dismutase is a virulence factor produced by the coral bleaching pathogen Vibrio shiloi. Curr Microbiol 46:418-422

Ben-Haim Y, Zicherman-Keren M, Rosenberg E (2003) Temperature-regulated bleaching and lysis of the coral Pocillopora damicornis by the novel pathogen Vibrio coralliilyticus. Appl Environ Microbiol 69:4236-4242

Blanford S, Thomas MB, Pugh C, Pell JK (2003) Temperature checks the Red Queen? Resistance and virulence in a fluctuating environment. Ecol Lett 6:2-5

Borger JL, Steiner SCC (2005) The spatial and temporal dynamics of coral diseases in Dominica, West Indies. Bull Mar Sci 77:137-154

Bourne D, Iida Y, Uthicke S, Smith-Keune C (2008) Changes in coral-associated bacterial communities during a bleaching event. ISME J 2:350-363

Brandt ME, McManus JW (2009) Disease incidence is related to bleaching extent in reef-building corals. Ecology 90: 2859-2867

Brown BE (1997) Coral bleaching: causes and consequences. Coral Reefs 16:S129-S138

Bruckner AW, Bruckner RJ (1997) Outbreak of coral disease in Puerto Rico. Coral Reefs 16:260

Bruckner AW, Bruckner R (2006) Consequences of yellow band disease (YBD) on Montastraea annularis (species complex) populations on remote reefs off Mona Island, Puerto Rico. Dis Aquat Org 69:67-73

> Bruno JF, Selig ER, Casey KS, Page CA and others (2007) Thermal stress and coral cover as drivers of coral disease outbreaks. PLoS Biol 5:e124, doi:10.1371/journal.pbio. 0050124

Clarke KR, Warwick RM (2001) Change in marine communities: an approach to statistical analysis and interpretation, 2nd edn. PRIMER-E, Plymouth

Cróquer A, Weil E, Zubillaga AL, Pauls SM (2005) Effects of white plague disease-II outbreak on the coral community structure of Madrizquí Key, Los Roques National Park, Venezuela. Caribb J Sci 41:815-823

Dobson AP, Hudson PJ (1998) Microparasites: observed patterns in wild animal populations. In: Gerenfell BT, Dobson AP (eds) Ecology of infectious diseases in natural populations. Cambridge University Press, Cambridge, p 51-89

> Dube D, Kim K, Alker AP, Harvell CD (2002) Size structure and geographic variation in chemical resistance of sea fan corals Gorgonia ventalina to a fungal pathogen. Mar Ecol Prog Ser 231:139-150
Ebert D, Zschokke-Rohringer CD, Carius HJ (1998) Within and between population variation for resistance of Daphnia magna to the bacterial endoparasite Pasteuria ramosa. Proc R Soc Lond B Biol Sci 265:2127-2134

Gilbert GS, Sousa WP (2002) Host specialization among wood-decay polypore fungi in a Caribbean mangrove forest. Biotropica 34:396-404

Gladfelter WB (1982) White-band disease in Acropora palmata: implications for the structure and growth of shallow reefs. Bull Mar Sci 32:639-643

> Glynn PW, D'Croz L (1990) Experimental evidence for high temperature stress as the cause of El Niño-coincident mortality. Coral Reefs 8:181-191

> Harvell CD (1990) The ecology and evolution of inducible defense. Parasitology 100:S53-S61

Harvell DC, Fenical W (1989) Chemical and structural defenses of Caribbean gorgonians. Limnol Oceanogr 34:382-389

Harvell D, Kim K, Quirolo C, Weir J, Smith G (2001) Coral bleaching and disease: contributors to 1998 mass mortality in Briareum asbestinum (Octocorallia, Gorgonacea). Hydrobiologia 460:97-104

> Harvell CD, Mitchell CE, Ward JR, Altizer S, Dobson AP, Ostfeld RS, Samuel MD (2002) Climate warming and disease risk for terrestrial and marine biota. Science 296: $2158-2162$

> Harvell CD, Aronson R, Baron N, Connell J, and others (2004) The rising tide of ocean diseases: unsolved problems and research priorities. Front Ecol Environ 2:375-382

Harvell CD, Markel S, Jordan-Dahlgren E, Raymundo L and others (2007) Coral disease, environmental drivers and the balance between coral and microbial associates. Oceanography (Wash DC) 20:36-59

Harvell CD, Altize SR, Cattadori IM, Harrington L, Weil E (2009) Climate change and wildlife diseases: When does the host matter the most? Ecology 90:912-920

Hoegh-Guldberg O (1999) Climate change, coral bleaching and the future of the world's coral reefs. Mar Freshw Res 50:839-866

Hoegh-Guldberg O, Mumby PJ, Hooten AJ, Steneck RS, and others (2007) Coral reefs under rapid climate change and ocean acidification. Science 318:1737-1742

> Hughes TP, Baird AH, Bellwood DR, Card D and others (2003) Climate change, human impacts and the resilience of coral reefs. Science 301:929-933

> Israely T, Banin E, Rosenberg E (2001) Growth, differentiation and death of Vibrio shiloi in coral tissue as a function of seawater temperature. Aquat Microb Ecol 24:1-8

Jolles A, Sullivan P, Alker AP, Harvell CD (2002) Disease transmission of aspergillosis in sea fans: inferring process from spatial pattern. Ecology 9:2373-2378

Jones RJ, Bowyer J, Hoegh-Guldberg O, Blackall LL (2004) Dynamics of a temperature-related coral disease outbreak. Mar Ecol Prog Ser 281:63-77

Kim K, Alker AP, Shuster K, Quirolo C, Harvell CD (2006) Longitudinal studies of aspergillosis in sea fan corals. Dis Aquat Org 69:95-99

Kuta KG, Richardson LL (2002) Ecological aspects of black band disease of corals: relationships between disease incidence and environmental factors. Coral Reefs 21:393-398

> Lesser MP (2004) Experimental biology of coral reef ecosystems. J Exp Mar Biol Ecol 300:217-252

> Miller J, Waara R, Muller E, Rogers C (2006) Coral bleaching and disease combine to cause extensive mortality on corals reefs in US Virgin Islands. Coral Reefs 25:418

> Miller J, Muller E, Rogers C, Waara R and others (2009) Coral disease following massive bleaching in 2005 causes $60 \%$ 
decline in coral cover on reefs in the US Virgin Islands. Coral Reefs 28:925-937

Mitchell CE, Tilman D, Groth JV (2002) Effects of grassland plant species diversity, abundance, and composition on foliar fungal disease. Ecology 83:1713-1726

Muller EM, Rogers CS, Spitzack AS, van Woesik R (2008) Bleaching increases likelihood of disease on Acropora palmata (Lamarck) in Hawksnest Bay, St John, Virgin Islands. Coral Reefs 27:191-195

Mydlarz LD, Holthouse SF, Peters EC, Harvell DC (2008) Cellular responses in sea fan corals: granular amoebocytes react to pathogen and climate stressors. PLoS One 3: e1811, doi:10.1371/journal.pone.0001811

Nugues MM (2002) Impact of a coral disease outbreak on coral communities in St Lucia: What and how much has been lost? Mar Ecol Prog Ser 229:61-71

Petes LE, Harvell CD, Peters EC, Webb MAH, Mullen KM (2003) Pathogens compromise reproduction and induce melanization in Caribbean sea fans. Mar Ecol Prog Ser 264:167-171

Poulin R, Marshall RJ, Spencer HG (2000) Metazoan parasite species richness and genetic variation among freshwater fish species: cause or consequence? Int J Parasitol 30: 697-703

Richardson LL, Kuta KG (2003) Ecological physiology of the black band disease cyanobacterium Phormidium corallyticum. FEMS Microbiol Ecol 43:287-298

Richardson LL, Voss JD (2005) Changes in a coral population on reefs of the northern Florida Keys following a coral disease epizootic. Mar Ecol Prog Ser 297:147-156

Rodriguez S, Cróquer A (2008) Dynamics of black band disease in a Diploria strigosa population subjected to annual

Editorial responsibility: Kiho Kim, Washington, DC, USA upwelling on the northeastern coast of Venezuela. Coral Reefs 27:381-388

Stedman TL (2000) Stedman's medical dictionary, 27th edn. Lippincott Williams \& Wilkins, Baltimore, MD

Stevens RB (1960) Cultural practices in disease control. In: Horsfall JG, Dimond AE (eds) Plant pathology, an advanced treatise, Vol 3. Academic Press, New York, p 357-429

Thomas MB, Blanford S (2003) Thermal biology in insectparasite interactions. Trends Ecol Evol 18:344-350

> Thompson DM, van Woesik R (2009) Corals escape bleaching in regions that recently and historically experienced frequent thermal stress. Proc R Soc Lond B Biol Sci 276: 2893-2901

Underwood AJ (1999) Experiments in ecology, their logical design and interpretation using analysis of variance. Cambridge University Press, Cambridge

> Vollmer SV, Kline DI (2008) Natural disease resistance in threatened staghorn corals. PLoS One 3:e3718, doi: 10.1371/journal.pone.0003718

Ward JR (2007) Within-colony variation in inducibility of coral disease resistance. J Exp Mar Biol Ecol 352:371-377

> Ward JR, Rypien KL, Bruno JF, Harvell CD and others (2006) Coral diversity and disease in Mexico. Dis Aquat Org 69: $23-31$

Ward JR, Kim K, Harvell CD (2007) Temperature affects coral disease resistance and pathogen growth. Mar Ecol Prog Ser 329:115-121

> Weil E, Cróquer A, Urreiztieta I (2009) Yellow band compromises the reproductive output of the Carribean reef-building coral Montastrea faveolata (Anthozoa, Scleractinia). Dis Aquat Org 87:45-55

Submitted: January 13, 2009; Accepted: October 14, 2009 Proofs received from author(s): November 4, 2009 